\title{
OBOWIAZZKI INFORMACYJNE NA GŁÓWNYM PARKIECIE GPW ORAZ NA RYNKU NEWCONNECT - ANALIZA PORÓWNAWCZA
}

\author{
Karolina Chamska \\ Wydział Ekonomiczny \\ Uniwersytet Gdański \\ Grzegorz Ściński \\ Wydział Ekonomiczny \\ Uniwersytet Gdański
}

\section{Streszczenie}

Nie sposób jest wyeliminować zjawiska asymetrii informacji na współczesnym ryku kapitałowym. Aby ograniczyć jego negatywne skutki nakładane są przez organizatorów obrotów instrumentami finansowymi obowiązki informacyjne. Emitenci papierów wartościowych na głównym parkiecie GPW oraz na alternatywnym systemie obrotu NewConnect są zobowiązani prezentować podstawowe dane o przedsiębiorstwie, jego stanie posiadania jak również okresowe raporty z jego bieżącego funkcjonowania oraz prospekty emisyjne. Z uwagi na charakter poszczególnych rynków obowiązki te są mniej lub bardziej restrykcyjne. Celem artykułu jest dokonanie porównania obowiązków informacyjnych pomiędzy rynkami akcyjnymi prowadzonymi przez GPW SA oraz dokonania oceny słuszności zastosowania danych rozwiązań. W artykule stawia się tezę, że bardziej restrykcyjne wymogi informowania akcjonariuszy dotyczące zmian dotykających spółkę giełdową mają bezpośrednie przełożenie na transparentność oraz ocenę jakości rynku w oczach inwestorów. Badanie zostało przeprowadzone poprzez dokonanie analizy porównawczej opartej na regulaminach obu parkietów oraz aktualnie obowiązującym stanie prawnym.

Słowa kluczowe: informacja, GPW, obowiązki Informacyjne, Alternatywny System Obrotu.

JEL Class: P33, P34, P45. 


\section{WPROWADZENIE}

Informację rynkową postrzega się jako „sygnał możliwy do przetworzenia i wykorzystania przez umysł do własnych celów związanych z daną inwestycją na rynku" [Górecki 2007: 54]. Innymi słowy, dzięki informacji uczestnicy rynku mają szansę zapoznać się z danymi, które po przetworzeniu stają się ich źródłem wiedzy, umożliwiając im dokonywanie świadomych wyborów ekonomicznych. Powszechna dystrybucja informacji sprawia, że rynek staje się przejrzysty, a ryzyko inwestycyjne maleje powodując, że ogólne bezpieczeństwo obrotu wzrasta [Szymański i Kocemba 2013: 20-21]. Jednakże pomimo wszelkich zalet płynących ze sprawnego obiegu informacji, dość powszechnym procederem jest zatajanie przez przedsiębiorców pewnych danych związanych z prowadzeniem przez nich działalności gospodarczej. Rozwiązania tego problemu możemy dopatrywać się we wszelkiego rodzaju regulacjach prawnych, które wymagają od przedsiębiorcy dystrybucji informacji na swój temat. Dzięki temu uczestnicy obrotu mają zagwarantowany dostęp do kompleksowych danych przedsiębiorców - ich kondycji finansowej, stosunkach organizacyjnych, perspektywach rozwoju itd. Jednakże żaden reżim ustawowych obowiązków informacyjnych nie jest w stanie wyeliminować zjawiska asymetrii informacyjnej.

Asymetria informacyjna należy do najbardziej klasycznych niedoskonałości obrotu gospodarczego. Powstaje w momencie gdy jeden $\mathrm{z}$ uczestników obrotu posiada większą wiedzę oraz dysponuje lepszymi informacjami niż pozostali. Zatem osoba, będąca w bardziej uprzywilejowanej informacyjnie sytuacji może podejmować swoje decyzje gospodarcze w sposób o wiele bardziej świadomy oraz bezpieczny. Podczas gdy drugi uczestnik obrotu, którego charakteryzuje stosunkowo gorszy dostęp do informacji ma wiedzę ograniczoną i ponosi większe ryzyko utraty ulokowanych środków. Przy czym koszty jakie musiałaby ponieść osoba gorzej poinformowana $\mathrm{w}$ celu uzupełnienia swej wiedzy oraz posiadanych informacji, są zbyt duże porównując ją z wymiarem korzyści jakie w ten sposób można by osiągnąć [Szymański i Kocemba 2013: 201-202].

Współczesne ukształtowanie obowiązków informacyjnych tworzy bardzo złożony system, który w sposób możliwie najlepszy zabezpiecza rynek przed niebezpieczeństwem jakim jest deficyt informacyjny. Praktyka pokazuje, że system ten nie jest idealny, dlatego też jest on przedmiotem debaty prawodawcy ze środowiskiem rynku kapitałowego. Dotyczy ona wszelkiego rodzaju rozważań związanych z kształtem regulacji prawnych (nakładających na uczestników obrotu gospodarczego obowiązki informacyjne) oraz propozycji ich zmian, które spowodowałyby usprawnienie realizacji tych powinności [Szymański i Kocemba 2013: 202-203]. 
Celem artykułu jest dokonanie porównania obowiązków informacyjnych pomiędzy rynkami akcyjnymi prowadzonymi przez GPW SA oraz oceny słuszności zastosowania danych rozwiązań.

\section{CHARAKTERYSTYKA RYNKU REGULOWANEGO}

Rynek kapitałowy oferuje różnego rodzaju usługi wspierające inwestycje finansowe. Ich wspólną cechą jest dokonywanie operacji instrumentami, które mają termin zapadalności powyżej roku. Wyróżniamy cztery podstawowe kategorie usług, sklasyfikowane według kryterium rodzaju świadczenia (1) usługi inwestycyjne, (2) usługi zbiorowego inwestowania, (3) usługi transakcyjne, (4) usługi ewidencyjne, rozliczeniowe i rozrachunkowe. Podmioty, które występują z propozycją świadczenia tych usług mają status instytucji zaufania publicznego. Zatem ich działalność na rynku finansowym podlega szczególnemu reżimowi prawnemu [Mroczkowski 2014: 141].

Usługi transakcyjne charakteryzuje to, że są świadczone w sposób bezpośredni na rzecz emitentów, zezwalając ich instrumentom finansowym do udziału w obrocie na rynku regulowanym. Powyższe usługi świadczone są przez spółki, które prowadzą rynki regulowane, czyli między innymi giełdę. Na podstawie definicji legalnej, która została zawarta w art. 4 ust. 1 pkt 14 dyrektywy 2004/39/WE Parlamentu Europejskiego i Rady z dnia 21 kwietnia 2004 r. w sprawie rynków instrumentów finansowych zmieniającej dyrektywę Rady 85/611/EWG i 93/6/EWG i dyrektywę 2000/12/WE Parlamentu Europejskiego i Rady oraz uchylającą dyrektywę Rady 93/22/EWG można wymienić następujące cechy charakteryzujące rynki regulowane:

- ich funkcjonowanie oparte jest na wielostronnym systemie obrotu

- kojarzą lub pomagają w kojarzeniu różnego rodzaju transakcji kupna oraz sprzedaży instrumentów finansowych

- funkcjonują w sposób systematyczny

- pozwalają na zawieranie umów odnoszących się do instrumentów finansowych dopuszczonych do obrotu

Zgodnie z definicją ujętą w ustawie o obrocie instrumentami finansowymi rynkiem regulowanym jest działający w sposób stały system obrotu instrumentami finansowymi dopuszczonymi do tego obrotu, zapewniający inwestorom powszechny i równy dostęp do informacji rynkowej w tym samym czasie przy kojarzeniu ofert nabycia i zbycia instrumentów finansowych, oraz jednakowe warunki nabywania i zbywania tych instrumentów, zorganizowany i podlegający nadzorowi właściwego organu [Ustawa z dnia 29 lipca 2005 r. ..., Art. 14, ust. 1]. Rynek regulowany jest prowadzony w formie giełdy lub rynku pozagiełdowego. W Polsce spółką prowadzącą giełdę jest Giełda Papierów Wartościowych S.A. 
w Warszawie. Jej członkowie poprzez system transakcyjny mają możliwość obrotu papierami wartościowymi (przykładem są akcje, prawa poboru, obligacje) oraz instrumentami finansowymi niebędącymi papierami wartościowymi, ale włączonymi do obrotu na rynku regulowanym (przykładem mogą być kontrakty terminowe lub opcje). Działalność spółek zajmujących się prowadzeniem giełdy na obszarze Unii Europejskiej podlega licencjonowaniu na podstawie ustawodawstwa krajowego (wspomniana wcześniej ustawa o obrocie instrumentami finansowymi), które jest zharmonizowane z dyrektywą 2004/39/WE Parlamentu Europejskiego i Rady z dnia 21 kwietnia 2004 r. w sprawie rynków instrumentów finansowych. Obowiązkiem tych spółek jest spełnienie sprecyzowanych w tych przepisach wymogów ostrożnościowych, które odnoszą się do tych spółek (wymogi kapitałowe i personalne) oraz ich działalności w kwestii prowadzenia rynku regulowanego (np. związanymi z wymogiem organizacyjnym) [Mroczkowski 2014: 147].

\section{OBOWIĄZKI INFORMACYJNE EMITENTÓW NA GŁÓWNYM PARKIECIE GPW}

Spółki publiczne, które chcą by ich akcje były dopuszczone do obrotu na tym rynku, muszą przestrzegać nakładanych na nie regulacji prawnych jakimi są szczególne obowiązki informacyjne. Tego rodzaju obowiązki dotyczą ochrony interesów zarówno akcjonariuszy jak i kontrahentów na rynku regulowanym. Powinności te reguluje art. 7 ust. 1 oraz art. 56 ust. 1 ustawy z dnia 29 lipca 2005r. o ofercie publicznej i warunkach wprowadzania instrumentów finansowych do zorganizowanego systemu obrotu oraz o spółkach publicznych [Sójka 2008: 54-55].

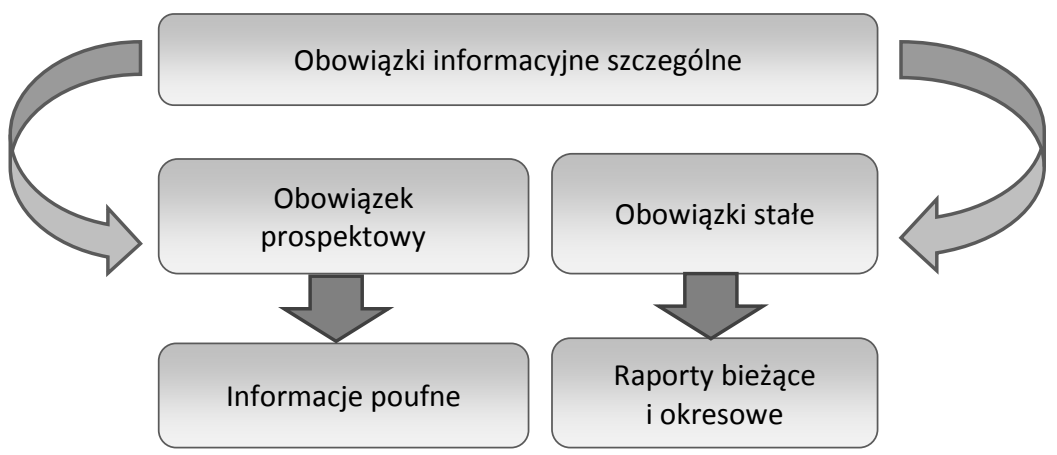

Rysunek 1. Obowiązki informacyjne spółek

Źródło: opracowanie własne. 
Aby spełnić obowiązek prospektowy należy sporządzić prospekt emisyjny, który w następnym etapie musi być zatwierdzony przez Komisję Nadzoru Finansowego oraz podany do publicznej wiadomości. Prospekt emisyjny to dokument dzięki, któremu ma miejsce transakcja między sprzedającym papiery wartościowe w ofercie publicznej a kupującym. Stanowi on jedno z wielu źródeł informacji, który jest podstawą oceny atrakcyjności oferty emitenta przez inwestorów. Wszelkie zawarte tam informacje są prawdziwe - poświadczają to oświadczenia sporządzone przez konkretne osoby i firmy, dlatego też inwestorzy mogą być pewni, że prospekty emisyjne są wiarygodne i pewne [Poślad 2007: 12].

Drugim rodzajem obowiązków są obowiązki stałe, które powstają od chwili złożenia wniosku do Giełdy Papierów Wartościowych o dopuszczenie jego walorów do obrotu na rynku regulowanym i trwają dopóki akcje danego emitenta pozostają w tym obrocie [Sójka 2008: 92]. Obowiązki te dzielimy na informacje poufne oraz na raporty bieżące i okresowe.Informacją poufną zgodnie $\mathrm{z}$ art. 154 Ustawy o obrocie jest taka informacja, która:

- dotyczy, bezpośrednio lub pośrednio, jednego lub kilku emitentów instrumentów finansowych, lub instrumentów finansowych (w tym nabywania lub zbywania takich instrumentów),

- jest określona w sposób precyzyjny,

- nie została przekazana do publicznej wiadomości,

- po przekazaniu do publicznej wiadomości mogłaby w istotny sposób wpłynąc na cenę instrumentów finansowych lub na cenę powiązanych z nimi pochodnych instrumentów finansowych.

Ostatnia z powyższych cech wskazuje, że informacja poufna jest cenotwórcza $\mathrm{z}$ tego też powodu jest ona informacją wartościową (jest brana pod uwage w momencie podejmowania decyzji inwestycyjnych), która natychmiast powinna być przekazana inwestorom [Pachucki i Plutecki 2014]. Dzięki temu gwarantuje to inwestorom podejmowanie tego rodzaju decyzji (dotyczących papierów wartościowych), których wartość odzwierciedla faktyczną sytuację ekonomiczną i gospodarczą emitenta [Szymański i Kocemba 2013: 133].

Podobną rolę pełnią raporty. Dzięki ich publikacji inwestorzy mają możliwość skorzystania z bieżących i periodycznych komunikatów, które oprócz wyposażenia ich w stałą wiedzę dotyczącą spółki, umożliwiają im dokładną ocenę jej sytuacji. Dokonując tego poprzez analizę porównawczą jej historycznych wyników lub konfrontacji z sukcesami innych spółek. Zgodnie z wymogami głównego rynku GPW, spółki notowane muszą publikować:

- raporty bieżące, które zawierają informacje o zdarzeniach dotyczących emitenta lub jednostki od niego zależnej, które zostały wymienione w rozporządzeniu Ministra Finansów, oraz inne informacje wydawane na podstawie przepi- 
sów ustaw (m.in. nabywanie i zbywanie znacznych pakietów, czy też transakcje osób pełniących określone funkcje w spółce).

- raporty kwartalne za I, III i IV kwartał, zawierające kwartalne skrócone sprawozdanie finansowe, niepodlegające badaniu,

- raporty półroczne za pierwsze półrocze roku obrotowego, zawierające półroczne skrócone sprawozdanie finansowe, które zostało poddane przeglądowi przez biegłego rewidenta

- raporty roczne - zawierają roczne sprawozdanie finansowe, przygotowane zgodnie $\mathrm{z}$ obowiązującymi zasadami rachunkowości oraz zbadane przez podmiot, który ma uprawnienia do badania sprawozdań finansowych.

Wszystkie sprawozdania finansowe publikowane w raportach okresowych powinny być opracowane $\mathrm{w}$ zgodzie $\mathrm{z}$ zasadami rachunkowości obowiązującymi emitenta. W głównej mierze sprawozdania finansowe emitentów giełdowych, których siedziba znajduje się na terytorium Rzeczpospolitej są sporządzane według reguł MSR/MSSF. Jednakże w przypadku pojedynczych jednostek, które nie tworzą grup kapitałowych, sprawozdania mogą być sporządzane według Polskich Standardów Rachunkowości [www 1].

\section{GENEZA, CELE ORAZ ROLA RYNKU NEWCONNECT NA POLSKIM RYNKU GIEŁDOWYM}

Doskonałym źródłem finansowania zewnętrznego jest rynek giełdowy. Przedsiębiorstwo „wchodzące na giełdę” staję się jednocześnie spółką publiczną co jest związane z poniesieniem dodatkowych kosztów. Emisja papierów wartościowych przez podmiot gospodarczy obarczona jest stosunkowo wysokimi wymogami dotyczącymi historii działalności gospodarczej, posiadanego kapitału oraz osiągania bardzo dobrych wyników finansowych. Wzrastający popyt na kapitał wyrażany przez nowo powstałe innowacyjne przedsiębiorstwa jak i brak możliwości jego zaspokojenia za pomocą tradycyjnego rynku regulowanego doprowadziło do powołania obok głównych parkietów rynków dedykowanych dla małych i średnich przedsiębiorstw [Mosionek-Szweda 2012b: 1]. Rynki te są określane przez Dyrektywę 2004/39/WE Parlamentu Europejskiego i Rady z dnia 21 kwietnia 2004 roku, dotycząca rynku instrumentów finansowych jako ,junior market”. Na skutek wysokich progów wejścia na główny parkiet giełdy Warszawskiej na polskim rynku giełdowym wytworzyła się tzw. „luka kapitałowa" w finansowaniu podmiotów z sektora MSP [Mosionek-Szweda 2012a: 130-131]. Z wyżej wymienionych podwodów oraz w celu rozwoju Giełdy Papierów Wartościowych dnia 30 sierpnia 2007 roku powstał nowy rynek obrotu akcjami zorganizowany przez GPW poza rynkiem regulowanym nazwany NewConnect [Szczepanowski 2010: 79-80]. Jest to rynek, który główny nacisk 
kładzie na rozwoju małych oraz średnich innowacyjnych przedsiębiorstw o potencjale wzrostu [Feder-Sempach 2010: 40], oraz jak podaje M. MosionekSchweda ,poszukujących kapitału niezbędnego do rozwoju działalności”.

\section{OBOWIĄZKI INFORMACYJNE EMITENTÓW NA RYNKU NEWCONNECT}

Zasadniczym elementem umożliwiającym poprawne funkcjonowanie, każdego rynku finansowego jest ochrona inwestora za pomocą, równego dostępu do informacji [www 1]. Transparentność zostaje zapewniona za pomocą szeregu norm oraz regulacji zarówno unijnych jak i krajowych. Do najważniejszych aktów prawnych dotyczących rynków kapitałowych należy zaliczyć; dyrektywę 2004/39/WE Parlamentu Europejskiego i Rady z dnia 21 kwietnia 2004 roku w sprawie rynków instrumentów finansowych, rozporządzenia Parlamentu Europejskiego i Rady UE nr 596/2014 z dnia 16.04.2014 w sprawie nadużyć na rynku, ustawę polskiego sejmu z 29 lipca 2005 roku o obrocie instrumentami finansowymi, Dz.U. 2005, nr 183, poz. 1538, z późn. zm., kodeks spółek handlowych oraz regulaminy wewnętrzne. W przypadku polskiego rynku NewConnect jest to Regulamin Alternatywnego Systemu Obrotu.

Polski rynek alternatywny NewConnect powstał w szczególności dla małych oraz średnich przedsiębiorstw innowacyjnych o krótkiej historii działalności nie spełniających wymogów debiutu na głównym parkiecie giełdy aby umożliwić rzeczonym spółką uzyskanie środków pieniężnych na rynku publicznym [Mosionek-Szweda 2012a: 138]. Z uwagi na misję jaką powinien realizować nowy rynek ustanowiono stosunkowo liberalne obowiązki dotyczące komunikacji z inwestorami. Spółki giełdowe na rynku alternatywnym przekazują informacje swoim inwestorem za pomocą [Załącznik nr 3 do Regulaminu Alternatywnego Systemu Obrotu...: 1]:

- Raportów okresowych (raporty roczne oraz kwartalne)

- Dokumentu Informacyjnego

- Raportów bieżących.

Do innych istotnych sposobów komunikacji z inwestorami M. Mosionek-Schweda zalicza podtrzymywanie relacji za pomącą regularnych spotkań z analitykami, mediami finansowymi czy też przekazywanie bieżących informacji na temat spółki za pomocą strony internetowej [Mosionek-Szweda 2013: 305].

Jednym z podstawowych oraz najważniejszych obowiązków informacyjnych stawianym przez organy ustawodawcze nowym spółką notowanym na rynku NewConnect jest publikacja tzw. dokumentu informacyjnego. Cel jego publikacji jest analogiczny do prospektu emisyjnego występującego na rynku regulowanym tj. ,zaprezentowanie potencjalnym nabywcom walorów informacji o danej ofercie 
emisyjnej" [www 2]. Publikacja jest obarczona mniejszym poziomem restrykcji oraz poziomem szczegółowości od prospektu emisyjnego. $Z$ wyłączeniem pewnych wyjątków nie jest zatwierdzany przez Komisję Nadzoru Finansowego ale przez wybranego autoryzowanego doradcę [Mosionek-Szweda 2013: 298]. W sytuacji kiedy oferta sprzedaży walorów miała charakter niepubliczny sporządzany zostaje Dokument Informacyjny. Zgodnie z regulaminem Alternatywnego Systemu Obrotu, jest on zatwierdzany przez doradcę [www 3].

Dokument informacyjny powinien zawierać prawdziwe, rzetelne i kompletne dane o jednostce emitującej, jej sytuacji finansowej i prawnej oraz o objętych dokumentem instrumentach finansowych mających być przedmiotem wprowadzenia do obrotu $\mathrm{w}$ alternatywnym systemie (..), może zostać sporządzany w języku polskim lub angielskim [Załącznik Nr 1 do Regulaminu Alternatywnego Systemu Obrotu...: 2-10].

Podstawowe informacje na temat emitenta są przekazywane w raportach bieżących. Znajdują się tam informacje dotyczące między innymi powołania osoby zarządzającej lub nadzorującej, struktury kapitału zakładowego emitenta, zmianie praw z instrumentów finansowych, wybór biegłego rewidenta czy zawarcie umowy o wykonywanie czynności Autoryzowanego Doradcy. W raportach bieżących są również publikowane wiadomości dotyczące nałożenia kary na przedsiębiorstwo przez organizatora alternatywnego systemu obrotu [Załącznik Nr 1 do Regulaminu Alternatywnego Systemu Obrotu...: 2-13].

Raport bieżący zostaje sporządzany oraz przekazany inwestorom bezzwłocznie w każdej sytuacji istotnej z punktu widzenia formalnoprawnego spółki oraz inwestora. W szczególnych przypadkach raport bieżący może być opublikowany na 26 dni przed terminem walnego zgromadzenia. Jak podaje załącznik Nr 3 do Regulaminu Alternatywnego Systemu obrotu z dnia 8 maja 2016 roku; Raport zostaje sporządzony np. W przypadku zakończenia subskrypcji lub sprzedaży, powiązanej z emisją instrumentów finansowych z podaniem min. Daty rozpoczęcia oraz zakończenia subskrypcji, ceny po jakiej instrumenty finansowe były nabywane, liczby osób, które złożyły zapisy na instrumenty. Dodatkowo emitent jest zobowiązany podawać informacje do jakich zobowiązuje go polskie ustawodawstwo, np. zgodnie z art. 402 Kodeksu spółek handlowych muszą zostać podane informacje o wystąpieniu z żądaniem oraz informacja o zwołaniu nadzwyczajnego walnego zgromadzenia emitenta [Załącznik $\mathrm{Nr} 1$ do Regulaminu Alternatywnego Systemu Obrotu...: 4] czy podjęciu uchwały o podwyższeniu kapitału zakładowego zgodnie z art. 434§ 2 Kodeksu Spółek Handlowych lub w wypadku decyzji o wypłacie oraz wielkości dywidendy Zalącznik Nr 1 do Regulaminu Alternatywnego Systemu Obrotu...: 5-6].

W raportach bieżących emitent ma także obowiązek informować inwestora w sytuacji braku zastosowania zasad ładu korporacyjnego obowiązujących na podstawie dokumentu „Dobre Praktyki Spółek Notowanych na NewConnect”. 
W raportach okresowych emitent jest zobowiązany do przekazania sprawozdań finansowych oraz danych porównywalnych, które mogą być sporządzane i publikowane zgodnie ze standardami rachunkowości powszechnie akceptowanymi w skali międzynarodowej [Załącznik Nr 1 do Regulaminu Alternatywnego Systemu Obrotu...: 7]. Raporty okresowe publikowane są na ASO w dwóch wariantach $\mathrm{w}$ formach skonsolidowanych raportów rocznych oraz kwartalnych. W raporcie rocznym znajdują się roczne sprawozdanie finansowe za dany rok obrotowy obejmujące: bilans, rachunek zysków i strat, rachunek przepływów pieniężnych zbadany przez biegłego rewidenta, opinię biegłego rewidenta lub innego podmiotu uprawnionego do badań sprawozdań finansowych a także roczne sprawozdanie $\mathrm{z}$ działalności emitenta. Raport kwartalny zawiera min. sprawozdanie finansowe za dany kwartał zawierające: bilans, rachunek zysków i strat, rachunek przepływów pieniężnych oraz informacje o zmianach w kapitale własnym. Sukcesy oraz niepowodzenia podmiotu w okresie sporządzania raportu, liczbę zatrudnionych pracowników oraz wskazanie akcjonariuszy posiadających co najmniej 5\% głosów na walnym gromadzeniu [Załącznik Nr 1 do Regulaminu Alternatywnego Systemu Obrotu...: 10-13].

Zgodnie z załącznikiem $\mathrm{Nr} 3$ do Regulaminu ASO raporty roczne są przekazywane nie później niż pięć miesięcy od dnia bilansowego, na który zostało sporządzone roczne sprawozdanie finansowe a także nie później niż w dniu zwołania walnego zgromadzenia. Natomiast skonsolidowany roczny raport grupy kapitałowej wystosowany jest nie później niż pięć miesięcy od dnia bilansowego. Raporty kwartalne jak i skonsolidowany raport kwartalny dostarczane są nie później niż w terminie 45 dni od dnia zakończenia kwartału roku obrotowego, którego dotyczyły publikowany raport [Załącznik Nr 1 do Regulaminu Alternatywnego Systemu Obrotu...: 12-13].

W sytuacji, w której emitent lub jednostka zależna maja negatywny wpływ na działanie jednostki co skutkuje np. odstępstwem od terminów oraz zaniechań dotyczących działalności operacyjnej lub pogorszenia się sytuacji finansowej GPW S.A ma prawo zobowiązać podmiot zarejestrowany na liście Autoryzowanych Doradców do dokonania między innymi analizy finansowej emitenta oraz prognozy finansowej [Regulamin Alternatywnego Systemu Obrotu...: 21].

$\mathrm{Z}$ uwagi na bardziej liberalny próg wejścia na rynek alternatywny związany także z obowiązkiem informacyjnym emitenta zgodnie z przepisami regulaminu ASO, organ nadzorujący rynek NewConnect w sytuacji nierespektowania obowiązków informacyjnych może nałożyć kare dyscyplinarną w wysokości do 50 tys. zł oraz zawiesić obrót derywatami do czasu publikacji wymaganego raportu okresowego a także może podjąć decyzje w wykluczeniu akcji podmiotu $\mathrm{z}$ obrotu na rynku alternatywnym [www 4].

Zgodnie zasadami przekazywania informacji bieżących i okresowych $\mathrm{w}$ alternatywnym systemie obrotu na rynku NewConnect, wszystkie wyżej opisane 
raporty bieżące oraz okresowe są przekazywane za pomocą Elektronicznej Bazy Informacji (EBI) [Załącznik do Uchwały Nr 646/2011...]. W ramach ochrony prawa inwestora zgodnie z rozporządzeniem MAR emitent ma obowiązek przekazywania informacji poufnej do tzw. Official Appointed Mechanism oraz opublikowania tejże informacji poufnej na stronie internetowej oraz utrzymywać ją przez okres co najmniej 5 lat [www 5].

\section{ANALIZA PORÓWNAWCZA OBOWIĄZKÓW INFORMACYJNYCH NA GPW ORAZ ALTERNATYWNEJ PLATFORMIE OBROTU AKCYJNEGO NEWCONNECT}

Najważniejszą różnice pomiędzy dwoma rynkami obrotu można spostrzec na poziomie ich ogólnej charakterystyki. Jak wynika z przytaczanej w poprzednich rozdziałach dyrektywy 2004/39/WE Parlamentu Europejskiego i Rady z dnia 21 kwietnia w sprawie rynków instrumentów finansowych zmieniająca dyrektywę Rady 85/611/EWG u dyrektywę 2000/12/WE Parlamentu Europejskiego i Rady oraz uchylająca dyrektywę Rady 93/22/EWG oraz ustawy z 29 lipca 2005 roku o obrocie instrumentami finansowymi ASO nie jest rynkiem w pełni regulowanym a to oznacza, że nie istnieje powszechny obowiązek jednakowego dostępu do informacji. W regulaminie ASO zostały określne tylko wymagania dotyczące określenia kursów oraz warunki obrotu instrumentami finansowymi. W wypadku notowań na rynku regulowanym, ustawodawstwo zobowiązuje emitentów dopuszczonym do obrotu do zapewnienia pełnego oraz równego dostępu do informacji (także poufnej) na temat ich zbywania oraz nabywania, określania kursów itd. [www 6: 32-36].

Podstawową różnicą formalno-prawną występującą pomiędzy obydwoma rynkami jest forma dokumentu emisyjnego. Prospekt jestsporządzany na rynku regulowanym i zatwierdzany przez KNF. Nie jest on wymagany wobec emitentów na alternatywnym systemie obrotu. Jego funkcje zastępuje dokument informacyjny, który zatwierdza nie KNF a autoryzowany doradca działający w ramach GPW SA. Dokument ten charakteryzuję się podobną strukturą zawartym w nim informacji. Szczegółowość wymaganych danych jest jednak ograniczona w porównaniu do prospektu. Warto jest wskazać na fakt, iż podmioty notowane na rynku NewConnect oraz rynku głównym zobowiązane są do przekazywania raportów okresowych w konkretnej formie oraz w sprecyzowanych terminach. Oczywiście oba rynki różnią się pod kątem wymagań dotyczących ich zawartości. Cechą wspólną jest obowiązek przekazania inwestorom na rynku głównym jak i alternatywnym informacji poufnych.

W raportach rocznych oraz bieżących nie występują większe różnice. $\mathrm{Na}$ rynku NewConnect są publikowane tylko w węższym zakresie niż na GPW. 
Istotna zmiana pojawią się w raporcie kwartalnym. Rynek regulowany wymaga publikowania raportu za I, III oraz IV kwartał, zawierający sprawozdania finansowe. Wobec emitentów w ASO wymagane jest tylko opublikowanie wybranych pozycji bilansowych oraz rachunku zysków i strat [www 7]. Dokumenty wymagane na głównym parkiecie oraz na rynku alternatywnym są obarczone różnymi terminami publikacji co obrazuje tab. 1.

Tabela 1. Terminy przekazywania raportów okresowych przez emitentów akcji

\begin{tabular}{|c|c|c|}
\hline & Rynek Główny & NewConnect \\
\hline Kwartalny & $\begin{array}{l}\text { Raport za I i III kwartał roku obroto- } \\
\text { wego - nie później niż do } 45 \text { dni od } \\
\text { dnia zakończenia kwartału Nie ma } \\
\text { obowiązku dostarczania raportu za } \\
\text { II kwartał. } \\
\text { Zwolnienie z obowiązku przekazania } \\
\text { raportu za IV kwartał }\end{array}$ & $\begin{array}{l}\text { Nie można opublikować później niż } \\
\text { w terminie } 45 \text { dni od dnia zakończenia } \\
\text { kwartału. }\end{array}$ \\
\hline Półroczny & $\begin{array}{l}\text { Raport za pierwsze półrocze roku obro- } \\
\text { towego - nie później niż w terminie } \\
2 \text { miesięcy od zakończenia półrocza. }\end{array}$ & Nie dotyczy \\
\hline Roczny & $\begin{array}{l}\text { Nie później niż } 4 \text { miesiące od zakoń- } \\
\text { czenia roku obrotowego. }\end{array}$ & $\begin{array}{l}\text { Niezwłocznie po wydaniu opinii przez } \\
\text { organ opiniujący raport. Nie później niż } \\
\text { w terminie } 7 \text { dni od otrzymania przez } \\
\text { emitenta oraz nie później niż } 6 \text { miesię- } \\
\text { cy od dnia bilansowego. }\end{array}$ \\
\hline
\end{tabular}

Źródło: www.gpw.pl/biblioteka-gpw-pobierz?gpwl_id=38\&gpwlf_id=40.

Cechą wspólną jest sporządzanie sprawozdań finansowych względem zasad rachunkowość obowiązujących emitenta [www 7].

Można wskazać także różnice jakościowe, pomiędzy przedsiębiorstwami notowanymi na obu parkietach giełd, na poziomie płaszczyzny kontaktu z inwestorem. Jak podaje M. Mosionek-Schweda, zaledwie trzy z ośmiu notowanych w bieżącym roku spółek zagranicznych przygotowało dokument informacyjny w języku polskim a zaledwie dwie spółki przygotowały raporty okresowe w języku polskim tj. Orphee oraz AerFinance [Mosionek-Szweda 2013: 306]. Można odnotować także, bardziej prozaiczne problemy, utrudnionego kontaktu z emitentami; jak podaje portal gazetatrend.pl ponad połowa emaili wystosowanych przez inwestorów do emitentów nie doczekała się odpowiedzi [www 8].

Emitenci, których akcje są włączone do obrotu na rynku regulowanym prowadzonym przez GPW (Główny Rynek) przekazują wymagane informacje do wiadomości publicznej za pośrednictwem Elektronicznego Systemu Przekazywania Informacji (ESPI, który zarządzany jest przez Urząd Komisji Nadzoru Finansowego) do wskazanej agencji informacyjnej - w Polsce jest nią Polska 
Agencja Prasowa (PAP). W przypadku gdy akcje są wprowadzone do alternatywnego systemu obrotu na NewConnect emitenci przekazują informacje za pośrednictwem Elektronicznej Bazy Informacji (EBI), która jest administrowana przez Giełdę Papierów Wartościowych. Odpowiedzialność prawna związana $\mathrm{z}$ obowiązkiem raportowania istotnych informacji w przypadku rynku regulowanego (Główny Rynek GPW) sprowadza się do odpowiedzialności administracyjnej z kolei w przypadku alternatywnego systemu obrotu (Rynek NewConnect) do odpowiedzialności regulaminowej. W określonych przypadkach mamy również do czynienia z odpowiedzialnością karną oraz cywilną występującą na obu rynkach [www 9].

Jak podaje strona internetowa polskiego radia w celu ochrony inwestorów dnia 10 grudnia 2015 roku zostało wprowadzone regularne publikowanie informacji na temat wniosków złożonych przez emitentów w sprawie wprowadzenia akcji do obrotu. Zawiera ono informacje dotyczące daty złożenia wniosku, daty uchwały zarządu o wprowadzenie akcji do ASO jak i datę opublikowania dokumentu informacyjnego. Podobne rozwiązanie funkcjonuje na GPW SA [www 10].

\section{PODSUMOWANIE}

Rzetelna informacja stała się podstawą współczesnej działalności na giełdzie, która determinuje poprawność funkcjonowania rynków. Analizując obowiązki informacyjne na poszczególnych platformach można wyciągnąć, wnioski, iż stawiane przed emitentami wymogi dotyczące transparentności na obu rynkach akcyjnych warszawskiej giełdy są pod względem istotny oraz celów do siebie zbliżone. Spełniają podobne funkcje jednak $z$ uwagi na regulacje prawne, dotyczące treści i procedury ich publikowania oraz celu działalności rynków są w mniejszym lub większym stopniu rygorystyczne. Bez wątpienia mniej wymagające obowiązki informacyjne dotyczące dokumentów emisyjnych czy procesu raportowania obniżają koszty wejścia na alternatywny system obrotu. Może to jednak doprowadzić do serii nadużyć, ograniczenia kontaktu $\mathrm{z}$ inwestorem, a co za tym idzie obniżenia poziomu zaufania inwestorów.

\section{BIBLIOGRAFIA}

Feder-Sempach E., 2010, Rynki Alternatywne w strefie euro I Unii Europejskiej a Newconnect - Analiza porównawcza, „Acta Universitatis Lodziensis. Folia Oeconomica”, nr 238.

Górecki P., 2007, Informacje poufne na rynku kapitałowym: podstawowe problemy regulacji prawnej oraz pojęcie informacji poufnej $i$ insidera, „Czasopismo Kwartalne Całego Prawa Handlowego, Upadłościowego oraz Rynku Kapitałowego”, nr 1. 
Mosionek-Schweda M., 2012a, Koszty i korzyści transferu spótki z newconnect na rynek regulowany GPW S.A., „Zeszyty Naukowe Uniwersytetu Szczecińskiego nr 736: Finanse, Rynki Finansowe, Ubezpieczenia", nr 55.

Mosionek-Schweda M., 2012b, Rozwój giełdowych rynków dedykowanych małym i średnim przedsiębiorstwom na przyktadzie wybranych giełd na świecie, Wyższa Szkoła Bankowa w Toruniu, Katedra Finansów i Bankowości.

Mosionek-Schweda M., 2013, Aktywność zagranicznych emitentów na matym parkiecie warszawskiej giełdy papierów wartościowych, „Zarządzanie i Finanse”, nr 2, t. 2, zif.wzr.pl/pim/2013.

Mroczkowski R., 2014, Rynek kapitałowy, [w:] A. Drwiłło (red.), Podstawy finansów i prawa finansowego, Wydawnictwo Wolters Kluwer S.A., Warszawa.

Pachucki M., Plutecki A., 2014, Jak prawidłowo wypetniać obowiązi informacyjne. Poradnik dla emitentów, Komisja Nadzoru Finansowego, Warszawa.

Poślad M., 2007, Poradnik inwestora. Jak czytać prospekt emisyjny?, Komisja Nadzoru Finansowego, Warszawa.

Regulamin Alternatywnego Systemu Obrotu, Część ogólna, tekst ujednolicony według stanu prawnego z dnia 1 października $2016 \mathrm{r}$.

Sójka T., 2008, Obowiązki informacyjne spótek publicznych $i$ odpowiedzialność cywilna za ich naruszenie, Wydawnictwo Wolters Kluwer, Warszawa.

Szczepanowski P., 2010, Efektywność wzrostu i rozwoju spótek NewConnect w ujęciu sektorowym, „Współczesna Ekonomia”, t. 4, nr 1.

Szymański R., Kocemba K., 2013, Obowiąki informacyjne spółek publicznych, Wydawnictwo LexisNexis, Warszawa.

Ustawa z dnia 15 września 2000 r. Kodeks spółek handlowych, Dz.U. 2000, nr 94, poz. 1037.

Ustawa z dnia 29 lipca 2005 r. o obrocie instrumentami finansowymi, Dz.U. 2016, poz. 1636.

Załącznik do Uchwały Nr 646/2011 Zarządu Giełdy Papierów Wartościowych w Warszawie S.A. z dnia 20 maja 2011 r.Załącznik Nr 1 do Regulaminu Alternatywnego Systemu Obrotu, Rozdział 1, Postanowienia ogólne, stan prawny z dnia 3 lipca 2016 r.

Załącznik Nr 3 do Regulaminu Alternatywnego Systemu Obrotu, stan prawny z dnia 8 sierpnia 2016 r. Informacje bieżące i okresowe przekazywane w alternatywnym systemie obrotu na rynku NewConnect.

[www 1] www.gpw.pl [Strona internetowa GPW].

[www 2] www.findict.pl/slownik/prospekt-emisyjny [Strona internetowa FinDict].

[www 3] www.edukacjagieldowa.pl/wp-content/uploads/2015/08/NewConnect.pdf [Strona internetowa Edukacja giełdowa].

[www 4] www.newconnect.pl/pub/dokumenty_do_pobrania/Raporty_okresowe_NewConnect_ 10_02_2017.pdf [Strona internetowa NewConnect].

[www 5] www.newconnect.pl/pub/dokumenty_do_pobrania/MAR_zmiany_Regulamin_ASO.pdf [Strona internetowa NewConnect].

[www 6] http://www.newconnect.pl/pub/regulacje_prawne/new/Regulamin_ASO_UTP_zal_2.pdf [Załącznik nr 2 do regulaminu ASO Zasady obrotu instrumentami finansowymi w alternatywnym systemie obrotu].

[www 7] www.gpw.pl/Obowiazki_informacyjne [Strona internetowa GPW].

[www 8] www.gazetatrend.pl/artykuly/392-newconnect-inwestor-indywidualny-niekonieczniepozadany [Strona internetowa Miesięcznika Trend].

[www 9] https://www.gpw.pl/biblioteka-gpw-pobierz?gpwl_id=38\&gpwlf_id=40 [Strona internetowa GPW].

[www 10] www.gpw.pl/komunikaty_prasowe?ph_tresc_glowna_start=show\&ph_tresc_glowna_ cmn_id=56946 [Strona internetowa GPW]. 


\title{
OBLIGATIONS INFORMATION ON THE MAIN FLOOR OF THE WSE AND THE NEWCONNECT MARKET - COMPARATIVE ANALYSIS
}

\begin{abstract}
It is impossible to eliminate the phenomenon of information asymmetry in today's roar capital. To reduce the negative aspects of this phenomenon are imposed by the organizers of the turnover of financial instruments on the issuer's disclosure obligations. Issuers of securities on the main floor of the WSE and NewConnect alternative trading system are required to present basic information about the company, its ownership as well as periodic reports on the current functioning and prospectuses. Due to the nature of the various markets the disclosure obligations are more or less restrictive. The purpose of this article is to compare the information obligations between equity markets operated by the WSE and to assess the validity of data application solutions.
\end{abstract}

Keywords: information stock exchange, responsibilities information, alternative trading system solutions. 